\title{
Taxa de elocução de fala segundo a gravidade da gagueira*****
}

\author{
Speech rate according to stuttering severity
}

\author{
Cláudia Fassin Arcuri* \\ Ellen Osborn** \\ Ana Maria Schiefer*** \\ Brasília Maria Chiari***
}

*Fonoaudióloga. Doutoranda no Programa de Pós-Graduação do Departamento de Fonoaudiologia da Universidade Federal de São Paulo Escola Paulista de Medicina. Endereço para correspondência: Rua Cunha, 111 - cj 73 - São Paulo - SP CEP 04037-030

(clauarcuri@gmail.com).

**Fonoaudióloga. Mestre em Linguística pela Pontifícia Universidade Católica de Campinas. Professora Adjunto I do Departamento de Fonoaudiologia da Universidade Federal de São Paulo.

***Fonoaudióloga. Doutora em Distúrbios da Comunicação Humana pela Universidade Federal de São Paulo. Professora Adjunto I do Departamento de Fonoaudiologia da Universidade Federal de São Paulo.

****Trabalho Realizado no Departamento de Fonoaudiologia da Universidade Federal de São Paulo.

Artigo Original de Pesquisa

Artigo Submetido a Avaliação por Pares

Conflito de Interesse: não

Recebido em 02.04.2008.

Revisado em 27.06.2008; 11.08.2008; 24.11.2008.

Aceito para Publicação em 03.02.2009.

\begin{abstract}
Background: speech duration has been the subject of acoustic studies due to its relationship with rhythm and speech rate. The speech analysis of stutterers has revealed data which often differs from that found in non-stutterers. These differences most likely stem from timing disturbances related to speech motor control. Objective: to compare the speech rates of individuals presenting different stuttering severity levels. Method: participants were 6 adult stutterers with the following severity levels: 2 with mild stuttering; 2 with moderate stuttering and 2 with severe stuttering. The words "cavalo" (horse), "pipoca" (popcorn) and "tapete" (carpet) were introduced in a carrier phrase, "Digo......baixinho" (Say ......in a low voice). Each phrase was uttered by the researcher and then repeated aloud 3 times by the participants while being recorded in a computer. Utterances containing speech disruptions were discarded. Subsequently, timing measurements were made, using the Praat 4.2 software. Utterances were divided into segments delimited by two consecutive voice onsets, and speech rate was then calculated (number of vowel-vowel segments divided by the total sum of duration of the segments). The data were analyzed statistically using ANOVA. Results: the group with mild/moderate stuttering presented higher and similar speech rates, differing statistically from the group with severe stuttering, therefore indicating that the higher the severity of stuttering, the lower the speech rate. This difference seems to be related to difficulties in motor programming, affecting mainly the rhythm and the timing of discourse. Conclusions: the rate of fluent speech during a repetition task differentiated the studied individuals according to the severity of stuttering.
\end{abstract}

Key Words: Speech Disorders; Stuttering; Speech Acoustics; Speech Production Measurement.

\section{Resumo}

Introdução: o aspecto da duração da fala tem sido investigado acusticamente por estar relacionado ao ritmo e taxa de elocução. A análise da fala de gagos tem revelado dados, por vezes, diferentes daqueles encontrados nos não-gagos, devido às perturbações temporais no controle motor da fala do gago. Objetivo: comparar as taxas de elocução de indivíduos com diferentes gravidades de gagueira. Método: foram selecionados seis adultos gagos, tendo dois deles gagueira de grau leve, dois de grau moderado e dois grave. As palavras "cavalo", "pipoca" e "tapete" foram introduzidas na frase-veículo "Digo...... baixinho". Cada frase foi emitida pela pesquisadora e repetida em voz alta três vezes pelos indivíduos, com gravação em computador. Foram desconsideradas as frases em que ocorreram disfluências. Posteriormente, foram realizadas as medidas de duração, no programa Praat 4.2. As frases foram divididas em segmentos delimitados por dois onsets vocálicos consecutivos, e então, foram calculadas as taxas de elocução (número de segmentos vogal-vogal dividido pela soma total da duração dos segmentos). Os dados foram analisados através de ANOVA. Resultados: o grupo com gagueira de grau leve e moderado apresentou taxas de elocução semelhantes e maiores, diferenciando-se estatisticamente do grupo com gagueira grave, indicando que quanto maior a gravidade, menor a taxa de elocução. A diferença parece dever-se às dificuldades na programação motora que afetam principalmente o ritmo e a temporalidade do discurso. Conclusões: a taxa de elocução de fala fluente, durante tarefa de repetição, diferenciou os indivíduos estudados segundo a gravidade da gagueira.

Palavras-Chave: Distúrbio da Fala; Gagueira; Acústica da Fala; Medida da Produção da Fala. 


\section{Introduction}

Stuttering is characterized as a fluency disorder which manifests through involuntary breakdown in the flow of discourse. From a motor standpoint, it is a disorder affecting synchronization of one or more of the subsystems - breathing, phonation and articulation - involved in the production of speech, or the relationship among them.

The numerous aspects which characterize the pathology - linguistic, motor, emotional - make stuttering multidimensional with a genetic and neurofunctional basis. With regard to the typical rhythmic compromise in stuttering, prosodic processing is one of the fundamental underlying elements which go toward explaining this phenomenon1.

Given its complexity, there are several assessment procedures used, fully explained in the literature, which aid diagnosis. In addition, to increase diagnosis reliability and improve control of the therapeutic course, more objective criteria are being increasingly used2. Numbering among these are acoustic measures of speech of disfluent individuals.

The acoustic duration parameter is an objective measure employed in acoustic analysis of both voice and speech which is directly related with the rhythm and rate of speech3. These parameters have contributed toward improved understanding of the standards and processes which make up discourse and its alterations.

Acoustic assessment of speech in stutters has furnished information on acoustic aspects which enable inferences to be made regarding articulatory and physiologic aspects, often different to that found in the speech of non-stutterers. These differences mark the timing disturbances in motor control of speech present in the fluent and dysfluent discourse of individuals who manifest stuttering.

Thus, the aim of the present work was to compare speech rates of stutters on a phrase repetition task, for different degrees of severity.

\section{Method}

The study was conducted following approval by the Research Ethics Committee of UNIFESP (protocol $\mathrm{n}^{\circ}$. 0159/05).

A total of 6 adult individuals were selected (aged between 22 and 35 years; mean 26 years and 2 months) with stutter complaints, comprising 3 men and 3 women, between 2005 and 2006.

All were informed regarding the study and signed consent terms prior to undergoing conventional phonoaudiological assessment: anamnesis, assessment of communication, along with basic audiological assessment, and specific assessment of stuttering.

The specific stutter assessment entailed recording of spontaneous speech and reading, using a Digital Sony cam onto MiniDv tape, connected to a Plantronics, model Audio20, microphone headset in a soundproofed room. Recordings were transcribed canonically and dysfluencies subsequently mapped as typical or atypical according to criteria described by Andrade4. A minimum of 3\% atypical dysfluency was adopted as criteria for establishing diagnosis, followed by filling out of the specific stutter protocol - Stuttering Severity Instrument 35, in order to ascertain degree of severity.

The 6 individuals were rated into three degrees of severity: 2 presented a mild stutter, 2 moderate and 2 severe.

Given the proposal of the present study was to establish measurements of speech rate which allowed comparison amongst stutterers in terms of fluent discourse, speech analysis was performed in repetition mode since the assessor's speech model tends to facilitate production of fluent utterances in this class of task. Those sections of speech in which breakdown occurred upon production were rejected.

Three tri-syllabic paroxytone words, "pipoca"(popcorn), "cavalo" (horse) and "tapete" (carpet),were then selected and inserted into the vehicle phrase: "Say____ in a low voice", mirroring the approach of earlier studies3,6. Each phrase was drilled by the researcher in a random order, and repeated aloud by the participants at least 3 times, thus avoiding bias in the statistical analysis.

Speech samples were recorded in an acoustically sound-proofed room, using a laptop HP Pavillion ze5500, with a Plantronics model Audio20 headset type microphone, at an approximate distance of $10 \mathrm{~cm}$ from the individual's mouth, employing Sound Forge 4.5. software.

Linguistic studies indicate that the production of an utterance is created through a voice flow interrupted by consonant disturbances (Barbosa, 1995). Thus, the unit delimited by two consecutive voice onsets is denominated in the literature as vowel-vowel (VV). Based on this concept and in a bid to establish reliable duration measures, each spoken phrase was segmented into these units. Establishing this delimitation ensured adoption of 
phonic units which are isomorphic to accentual effects 3,7. Commencing with the assessed phrases, these were split into "D/ig/o p/ip/oc/a b/aix/inho", "D/ig/o c/av/al/o b/aix/inho", "D/ig/o t/ap/et/e b/ aix/inho", where VV units analyzed were: $\mathrm{iG}, \mathrm{Up}$, Uk, Ut, ip, av, ap, oK, aL, eTSH, Ab, Ub , ib, aish, while rejecting the initial ("d") and final ("inhu") segments.

The software Praat, version 4.3 was used to obtain the acoustic duration measures based on the following criteria:

a) Based on the wave form and the spectrogram of the digitalized speech signal, using the broad band spectrogram, where the visual aspect was the key criteria for the cut off between acoustic segments, with the auditory used merely for confirmation.

b) The unit cut offs were defined by the first regular burst of the vowel, and marking on the trough of the wave;

c) The first regular burst was determined by the uniformity of the amplitude and form of the wave, assisted by the activation of the formant tracking tool from the software.
To appraise reliability of the analyses, $50 \%$ of the data collected were randomly submitted to confirmation of acoustic measurement values by another speech therapist with experience in the area of acoustic analysis.

After collection of the data and establishing acoustic measurement duration (in milliseconds) the values obtained were compiled individually.

Subsequently, individual speech rates of the phrases produced were calculated, using the calculation of the number of segments (VV units) divided by the summed total duration of the segments considered.

The data collected and compiled as absolute numbers were then submitted to statistical analysis, by standardizing into Z-Score (elasticity index of the segment) and inputting to the Anova test (Variance Analysis). For the current study, a 0.05 $(5 \%)$ level of significance was adopted.

\section{Results}

Comparison of speech rates among stutterers and classification according to degree of severity is depicted in the Table below.

TABLE 1. Comparison of Speech Rates among stutterer group, classified according to degree of stutter severity.

\begin{tabular}{|c|c|c|c|c|c|c|c|}
\hline Z-Score & Group & $\mathrm{N}$ & Mean & $\begin{array}{l}\text { Standard } \\
\text { Deviation }\end{array}$ & $\mathrm{Cl}$ & $\begin{array}{c}\text { ANOVA } \\
(p)\end{array}$ & Result \\
\hline \multirow{4}{*}{ Cavalo } & Mild & 06 & 0.5847 & 0.2945 & 0.3 & \multirow{4}{*}{$<0.001$ * } & \multirow{4}{*}{$\begin{array}{c}\text { Mild }=\text { Mod }> \\
\text { Sev }\end{array}$} \\
\hline & & 06 & & & 0.3 & & \\
\hline & Moderate & & 0.6149 & 0.3688 & & & \\
\hline & Severe & 06 & -1.1996 & 0.7658 & 0.7 & & \\
\hline \multirow{4}{*}{ Pipoca } & Mild & 06 & 0.5047 & 0.5696 & 0.5 & \multirow{4}{*}{$<0.001$ * } & \multirow{4}{*}{$\begin{array}{c}\text { Mild }=\text { Mod }> \\
\text { Sev }\end{array}$} \\
\hline & & 06 & & & 0.3 & & \\
\hline & Moderate & & 0.6705 & 0.3118 & & & \\
\hline & Severe & 06 & -1.1752 & 0.6900 & 0.6 & & \\
\hline \multirow{4}{*}{ Tapete } & Mild & 06 & 0.6270 & 0.2115 & 0.2 & & \multirow{4}{*}{$\begin{array}{c}\text { Mild }=\text { Mod }> \\
\text { Sev }\end{array}$} \\
\hline & & 06 & & & 0.1 & \multirow{3}{*}{$<0.001^{*}$} & \\
\hline & Moderate & & 0.5860 & 0.1208 & & & \\
\hline & Severe & 06 & -1.2130 & 0.8315 & 0.7 & & \\
\hline
\end{tabular}

$*$ p-value $<0.05$ 


\section{Discussion}

In normal circumstances of fluency, the subject articulates several parts of the vocal tract smoothly and precisely. The faster these movements the higher the muscular activity, and in the event of overload, muscle contractions may occur causing oscillations and jitter.

Considering that speech is a fast motor control task and that activation and phonemic selection time is probably compromised in stutterers, it has been hypothesized that speech motor activity in stutterers may be slower8.

More than that, study showed that when stutters were inducted to change your speed speech, they were more susceptible to break their motor control9.

A motor system indicator with regard to speech is articulatory speed, determined by the number of syllables produced per minute4, whereas speech rate is defined as the number of segments of $\mathrm{VV}$ speech units divided by the sum of their duration. Thus, beginning an utterance rapidly or speaking rapidly places excessive burden on this system leading to breakdowns. In order for stutterers to produce fluent speech, greater activation and phonemic selection time is needed, resulting in a longer speech time than for non-stutterers.

The results obtained from comparison of degrees of stutter severity, in terms of speech rate for the three phrases studied, demonstrated that the mild to moderate stutterer groups present similar performance differing significantly to the group of severe stutterers. The individuals with severe degree of stutter presented positive Z-scores, in other words, lower rates of articulatory production.

These findings are in line with those from a study on the relationship between degree of stutter severity and information production rates (number of words produced per minute) and articulation rate (number of syllables produced per minute), conducted by Andrade et al.10, which observed that the higher the degree of stutter severity, the lower the information production and articulation rates of stutterers.

The speech rate influences the perception of the rhythmic type of speech. Slower speech rates may stem from a tendency for syllabization, extending of end stops and even silent pauses. Rapid speech rate however, tends to involve low syllabization rates 3 . Therefore, we may hypothesize that even under fluency circumstances stutterers will present a tendency for syllabization in order to optimize speech motor production.
Individuals with mild or moderate stutter severity presented similar patterns of motor adjustment, having similar performance in terms of speech rate. In contrast, individuals with severe degree of stutter demonstrated more compromised motor programming, resulting in a lower speech rate. This low speech rate may reflect a slower than usual working mechanism 11.

The finding of lower speech rates in stutterers may be explained both by the greater time required to process linguistic and phonologic information, and the underlying neuromotor and rhythmic disorder, which are directly linked to articulation rates and impact compensatory control movements12. It is assumed that these difficulties are more prominent with increased severity. In other words, speech rates are lower particularly in severe stutterers, since stutterers manifest a delay in initial voicing and slower transitions, characteristics which become more marked as severity increases $2,11,13$ 15.

The differing speech rates observed in the sample of this study are most likely associated to the issue of word syllable duration and to sequential order of phonetic gaps.

Explanations for this may be found in the model proposed by Perkins et al.16. According to this model, in order for speech to be fluent in terms of timing, at least two neural operating systems must be in balance before the message reaches the motor cortex. The first is the symbolic system, which involves cognitive, linguistic, phonologic (rhythm and intonation) and fragmental (start and finish) elements, and is responsible for determining the message form and content, namely, segmentation. The second is the signals system, which concerns prosody (frequency, intensity, duration) and determines the duration of the syllable in the word and the sequence order of phonetic gaps. Speech is fluent when both segmentation and ordering work hand in hand. However, when imbalance occurs the flow of speech is interrupted causing breakdown or dysfluencies.

We may therefore deduce that the different speech rates among mild, moderate and severe stutterers seen in the present study during fluent speech, demonstrate an imbalance in the signal system especially since this imbalance was more evident in severe stutterers.

Moreover, its is logical to propose that the inability of stutterers to process neural signals to execute the precise and swift movements of normal conversation, especially when under pressure in planning a complex sentence or competing with other 
speakers, is also related to the higher duration and consequently lower speech rates observed in stutterers11.

Speech motor control requires coordination of neural processes and sensory-motor mechanisms to enable fluent discourse 17-21. In stuttering, we are able to observe lack of coordination or breakdown in respiration, phonation and articulation when alterations manifest at any level of this control19. Under circumstances of fluency, stutterers can manifest slowed production, with resulting increase in acoustic duration, along with lower speech rate due to processing deficits.

The overall slowing in speech movements observed in stutterers, possibly having a sensorial root, is evident during fluent speech in an apparently harmonious manner, that is, the longer duration of output reflects the basic aspects of a mechanism underlying a disorder, or a motor strategy employed by stutterers, preventing or minimizing dysfluency episodes 19.

The valuable contribution of speech rate differences in the assessment, diagnosis and therapy of stutterers is clear2,22.

In the presence of low speech rates, we must endeavor to reduce speech speed as a treatment strategy, not only to simplify production through smoother articulatory programming of each unit, but also to stabilize the system and compensate the inherent instability of the speech motor mechanism in stutterers.

\section{Conclusions}

Fluent speech rates vary among stutterers with different degrees of stutter severity on a repetition task. Individuals with a severe degree of stutter present, even during fluent speech, lower speech rates than individuals with mild to moderate stutter, where these findings corroborate the hypothesis of an underlying deficit in timing and speech motor control.

The current study demonstrates the need for further studies which can improve understanding of this complex pathology and further elucidate on how the motor programming process differs in these subjects. Future studies could involve the application of instruments which can yield more objective numerical data and help to establish pre and post-treatment parameters.

In addition, studies which associate the aspects of acoustic duration with imaging, electromyography and other exams can collaborate toward explaining the role of programming, selection and motor execution factors as indicators of clinical manifestations of stuttering, thus contributing to better understanding and treatment of this pathology. 


\section{References}

1. Andrade CRF. Abordagem neurolingüística e motora da gagueira. In: Ferreira LP, Befi-Lopes DM, Limongi SCO, organizadoras. Tratado de Fonoaudiologia. São Paulo: Roca; 2004. p. 1001-16.

2. Bakker K. Instrumentation for the assessment and treatment of stuttering. In: Curlee, RF, Siegel GM. Nature and treatment of stuttering: new directions. 2nd ed. Boston: Allyn e Bacon; 1997. p. 377-97.

3. Barbosa PA. Incursões em torno do ritmo da fala. São Paulo: FAPESP; 2006.

4. Andrade CRF. Fluência. In: Andrade CRF, Befi-Lopes DM, Wertzner HF, Fernandes F. ABFW - Teste de Linguagem Infantil nas áreas de Fonologia, Vocabulário, Fluência e Pragmática. 2ed. Barueri - SP; 2004. p. 71-94.

5. Riley GD. Stuttering severity instrument for children and adults-SSI. Austin; 1994.

6. Colaccico FB, Schiefer AM, Osborn, E. Medidas Acústicas de duração da fala de indivíduos gagos e não-gagos. Fono Atual. 2005;31(8):26-30.

7. Matte ACF. Taxa de elocução, grupo acentual, pausas e fonoestilística: temporalidade na prosa e na poesia com interpretação livre. Estudos Lingüísticos. 2006;XXXV:27685

8. Ludlow CL, Loucks T. Stuttering: a dynamic motor control disorder. Journal of Fluency Disorders. 2003;28:27395 .

9. Smith A., Kleinow J. Kinematic Correlates of Speaking Rate Changes in Stuttering and Normally Fluent Adults. Journal of Speech, Language, and Hearing Research. 2000;43:521-36.

10. Andrade CRF, Cervone LM, Sassi FC. Relationship between the stuttering severity index and speech rate. São Paulo Medical Journal - Revista Paulista de Medicina. 2003;121(2):81-4.

11. Guitar B. Stuttering: An Integrated Approach to Its Nature and Treatment. 3rd ed. MD: Lippincott Williams Wilkins; 2006.
12. Hall K, Amir O, Yairi E. A longitudinal investigation of speaking rate in preschool children who stutter. Journal of Speech, Language, and Hearing Research. 1999;42:136777.

13. Di Simoni, FG. Preliminary study of certain timing relationships in the speech of stutterers. J. Acoust. Soc. Am. 1974;56(2):695-6.

14. Hillman RE, Gilbert HR. Voice onset time for voiceless stop consonants in the fluent reading of stutterers and nonstutterers. J. Acoust. Soc. Am. 1977;61(2):610-1.

15. Zimmermann G. Articulatory dynamics of fluent utterances of stutterers and non-stutterers. Journal of Speech, Language and Hearing Research. 1980;23:95-107.

16. Perkins WH, Kent RD, Curlee RF. A theory of neuropsycholinguistic function in stuttering. Journal of Speech, Language and Hearing Research. 1991;34:734-52.

17. Bailly G. Learning to speak-sensori-motor control of speech movements. Speech Communication. 1997;22:25167.

18. Kent RD. Research on speech motor control and its disorders: a review and prospective. J. Commun. Disord. 2000;33:391-428.

19. Max L, Guenther FH, Gracco VL, Ghosh SS, Wallace ME. Unstable or insufficiently activated internal models and feedback-biased motor control as sources of dysfluency: a theoretical model of stuttering, CICSD. 2004;31:10522 .

20. Max L, Caruso AJ, Gracco VL. Kinematic analyses of speech, orofacial nonspeech, and finger movements suggest generalized differences in neuromotor control between stuttering and nonstuttering individuals. Journal of Speech, Language and Hearing Research. 2003;46:215-32.

21. Max L, Gracco VL. Coordination of oral and laryngeal movements in the perceptually fluent speech of adults who stutter. Journal of Speech, Language, and Hearing Research. 2005;48:524-42.

22. Brosch S, Heage A, Johannsen HS. Prognostic indicators for stuttering: the value of computer-based speech analysis. Brain and Language. 2002;82:75-86. 